DOI: $10.33766 / 2524-0323.89 .149-162$

УДК 342.95(477)

Т. О. Коломоєць,

доктор юридичних наук, професор, член-кореспондент НАПрН України,

заслужений юрист України,

декан юридичного факультету

Запорізького національного університету (м. Запоріжжя, Україна) e-mail: T_deputy@ukr.net iDhttps:/ /orcid.org/0000-0003-1101-8073

В. К. Колпаков, доктор юридичних наук, професор, завідувач кафедри адміністративного та господарського права Запорізького національного університету (м. Запоріжжя, Україна) e-mail v.k.kolpakov@gmail.com iDhttps:/ / orcid.org/0000-0002-8580-3261

\title{
УНІВЕРСАЛІЇ «ФАКТИЧНА ОЗНАКА» ТА «ОЗНАКА ЮРИДИЧНОГО СКЛАДУ» В ПОНЯТТІ АДМІНІСТРАТИВНОГО ПРОСТУПКУ
}

У статті досліджується співвідношення універсалій «фактична ознака» та «ознака юридичного складу» в понятті адміністративного проступку. На підставі їхнього онтологогносеологічного аналізу розкрито зміст і практичне значення апостеріорних та апріорних ознак адміністративного проступку. Акцентовано увагу на ролі вказаних ознак у розробленні понять «суспільна шкідливість адміністративного правопорушення» та «суспільна небезпека адміністративного правопорушення». Запропоновано нове бачення генетичних витоків, правової природи, співвідношення та розуміння зазначених універсалій. На підставі здійсненого дослідження сформульоване доктринальне визначення поняття адміністративного правопорушення.

Ключові слова: адміністративне правопорушення; онтологія та гносеологія адміністративного правопорушення; фактичні ознаки та юридичний склад адміністративного правопорушення; суспільна небезпека і суспільна шкідливість адміністративного правопорушення.

Постановка проблеми. У джерелах, присвячених дослідженням властивостей адміністративного проступку, останнім часом спостерігається тенденщія щодо ототожнення змісту ознак проступку та ознак складу проступку [1, с. 35; 2, с. 49; 3, с. 44- 45]. Однак це різні універсалії поняття «адміністративне правопорушення (проступок)», про що один із співавторів цієї статті вже писав [4, с. 48-75]. Детермінація вказаних універсалій має істотне значення як для розвитку доктринальних положень адміністративно-деліктного права, так і для практики кваліфікації відповідних вчинків, накладення стягнень і запобігання адміністративним правопорушенням.

Аналіз останніх досліджень і публікацій. Загальні питання щодо визначення поняття кримінальних проступків, у тому числі їх ознак, розглядали у своїх працях

(С) Коломоєць Т. O., Колпаков В. К., 2020 
такі вчені, як: В. Б. Авер'янов, О. М. Бандурка, Ю. Ю. Басов, О. І. Безпалова, А. І. Берлач, Ю. П. Битяк, К. Л. Бугайчук, І. П. Голосніченко, С. Т. Гончарук, Т. О. Гуржій, С. М. Гусаров, С. Ф. Денисюк, В. В. Доненко, В. В. Зуй, Р. А. Калюжний, А. П. Клюшниченко, Л. В. Коваль, Ю. М. Козлов, В. К. Колпаков, А. Т. Комзюк, С.Ф.Константинов, І. М. Копотун, М. Й. Коржанський, О. В. Кузьменко, К. Б. Левченко, Д. М. Лук'янець, О. І. Миколенко, О. М. Музичук, В. О. Навроцький, С. Б. Ольховський, О. І. Остапенко, А. М. Подоляка, О. Ю. Салманова, О. Ю. Синявська, В.Ю. Стороженко, В. Г. Фатхутдінов, О. Л. Чернецький та ін. Проте, незважаючи на активізацію наукових досліджень із цих питань, аналіз фактичних ознак та ознак юридичного складу в контексті визначення поняття адміністративного проступку є недостатньо дослідженими і викликають багато запитань на практищі.

Аналіз ознак адміністративного проступку у вітчизняній юридичній літературі зазвичай обмежується цитуванням ст. 9 Кодексу України про адміністративні правопорушення (далі - КУпАП) і поясненням того, що таке дія, бездіяльність, винність, умисність, необережність, громадський порядок, власність, права і свободи громадян і встановлений порядок управління [5, с. 379-381]. Крім перелічених, до ознак адміністративного проступку включають суспільну шкоду [6, с. 150] або суспільну небезпеку [7, с. 242-243]. Непоодинокими є випадки, коли в описанні ознак адміністративного проступку шкода і небезпека фігурують як тотожні поняття $[8$, c. 92].

Це є свідченням того, що автори, по-перше, не обтяжують себе розумінням правової природи шкоди й небезпеки відповідно до конщепщії адміністративного проступку, по-друге, не усвідомлюють різниці між фактичними ознаками адміністративного проступку (апостеріорні, емпіричні, онтологічні) та ознаками юридичного складу такого проступку (апріорні, гносеологічні).

Формулювання цілей. Автори мають на меті дослідити співвідношення універсалій «фактична ознака» та «ознака юридичного складу» щодо поняття адміністративного проступку, розкрити зміст апостеріорних та апріорних ознак такого проступку й на підставі цього сформулювати вдосконалене доктринальне визначення поняття адміністративного проступку.

Виклад основного матеріалу. 3' ясування співвідношення між указаними групами ознак вважаємо за доречне розпочати з аналізу ст. 9 КУпАП. Саме в їі тексті зафіксовані найбільш загальні фактичні (апостеріорні) ознаки адміністративного проступку та апріорні ознаки юридичного складу адміністративного проступку. Отже, адміністративним правопорушенням (проступком) визнається протиправна, винна (умисна або необережна) дія чи бездіяльність, яка посягає на громадський порядок, власність, права і свободи громадян, на встановлений порядок управління і за яку законом передбачено адміністративну відповідальність.

Фактичними (від слова «факт» - те, що трапляється бути, випадок, подія зафіксована безпосередніми фізичними відчуттями як конкретно існуюча в конкретному часі реальність, що об'єктивно перевіряється, спостерігається, вимірюється і протилежна загальному й абстрактному) ознаками проступку є «дія» $\mathrm{i}$ «бездіяльність» (позначаються терміном «діяння»). Ці ознаки виявляються простим спостереженням відповідної події і фіксуються шляхом точного опису, який можна вважати калькою 
(від фр. «calque» - копія) діяння. Такі описи ми знаходимо в актах, протоколах, поясненнях, експертних висновках та інших аналогічних джерелах. Завдання таких описів - точно відтворити словами (поняттями) картину реальної дійсності в часі й просторі.

Ознаки, про які йдеться, є фактичними (емпіричними, апостеріорними, онтологічними), тобто ознаками події, яка трапилась у матеріальному світі та яка, за відповідних умов, може бути розцінена як адміністративний проступок. Отже, у частині ст. 9 КУпАП, присвяченій переліку фактичних ознак, розкрито онтологію адміністративного проступку. Однак наявності фактичних ознак недостатньо для юридично коректного висновку про те, що відповідний випадок $€$ (не є) адміністративним правопорушенням. Для такого остаточного висновку необхідно дослідити окремі специфічні (апріорні) властивості цих фактів. Найбільш загальні 3 них також подані у ст. 9 КУпАП.

Існують два різновиди таких властивостей: перший відбиває внутрішню природу діяння (протиправність, винність у формі умислу або необережності), а другий - зовнішню об́єктивацію діяння (дія або бездіяльність мають бути посяганням). Крім того, законодавець вводить у текст аналізованої статті КУпАП уточнення щодо суті посягання. Уточнення здійснено за двома параметрами: 1) за особливостями об'єктів; б) за галузевим змістом відповідальності. Щодо особливості об'єктів, то посягання має здійснюватись на громадський порядок, власність, права і свободи громадян, встановлений порядок управління. Щодо галузевого змісту відповідальності - посягання має підпадати під адміністративну відповідальність.

У продовження цієї тези сформульована ч. 2 ст. 9 КУпАП, де зазначено, що адміністративна відповідальність за правопорушення, передбачені цим Кодексом, настає, якщо порушення за своїм характером не тягнуть за собою відповідно до закону кримінальної відповідальності. Наведена норма є прямою вимогою враховувати кримінальний закон при зіткненні з подіями, які ймовірно можуть бути адміністративними правопорушеннями.

Осягнення перелічених вище специфічних властивостей діяння неможливо здійснити за допомогою лише онтологічного опису. Для цього потрібні інші юридичні засоби та інструментарій, які зорганізовані поняттям «склад адміністративного проступку». Про склад проступку йдеться в ст. 247 КУпАП «Обставини, що виключають провадження в справі про адміністративне правопорушення». Проте в цьому випадку законодавець уникнув будь-яких вказівок щодо розуміння поняття «склад адміністративного правопорушення (проступку)». Він лише зазначив, що провадження в справі про адміністративне правопорушення не може бути розпочато, а розпочате підлягає закриттю за відсутністю складу адміністративного правопорушення.

Склад проступку є узагальненою абстракцією. Це поняття і термін введено в науковий обіг для позначення результатів наукового, системного осмислення емпіричних (фактичних) знань про адміністративний проступок. Водночас слід зазначити, що «склад проступку» - поняття конкретне. Воно може застосовуватися лише до конкретного діяння, описаного в Особливій частині КУпАП.

Учення про склад правопорушення посідає одне з центральних місць в адміністративно-правовій науці і має велике практичне значення. По-перше, воно сприяє виявленню найбільш істотних ознак антигромадських діянь, їхньому розмежуванню і встановленню справедливих санкцій; по-друге, це вчення допомагає правозастосовним органам юридично коректно кваліфікувати правопорушення та 
обирати адекватні їм заходи впливу; по-третє, воно дозволяє зрозуміти закон, допомагає навчанню юристів і правовому вихованню громадян. Під складом адміністративного правопорушення розуміється описана в законі система апостеріорних і апріорних ознак конкретного діяння, за наявності яких воно (діяння) набуває статусу адміністративного правопорушення (проступку).

У зв' язку із наведеним вище, виникають такі питання: скільки ознак є у правопорушення? Які ці ознаки за своїми юридичними властивостями? Які з них є обов'язковими для визнання діяння адміністративним проступком, тобто утворюють його склад?

Цілком очевидно, що кожне конкретне правопорушення має величезну кількість ознак, що виділяють його із загальної маси проступків і роблять особливим, специфічним явищем реальної дійсності. За своїми юридичними властивостями ці ознаки поділяються на такі, (а) які мають юридичне значення (юридично значущі), і на ті, (б) які не мають юридичного значення (юридично незначущі). Юридично значущі ознаки, своєю чергою, поділяються на дві групи: по-перше, це ознаки, які входять до складу проступку (описані в законі) або, інакше кажучи, конструктивні ознаки; по-друге, ознаки, які не входять до складу проступку. До другої групи належать обставини, що пом'якшують (ст. 34 КУпАП), обтяжують (ст. 35 КУпАП), виключають (ст. 17 КУпАП) відповідальність тощо. Наявність у діянні конструктивних (які утворюють склад) ознак і робить певне діяння адміністративним правопорушенням. Навіть більше, реальне діяння тільки тоді вважається проступком, коли воно містить усі ознаки складу (відсутність хоча б однієї з них означає відсутність складу загалом). Усі інші ознаки проступку на його кваліфікацію не впливають.

Як випливає з дефініції (визначення) складу, ці ознаки повинні бути закріплені (описані) в законі. Засіб, за допомогою якого зазначені ознаки зафіксовані в законі, має важливе значення для розуміння суті складу адміністративного правопорушення. Існує щонайменше дві точки зору з приводу цієї проблеми. Відповідно до першої - ознаки складу проступку закріплюються в статтях Особливої частини КУпАП. Ця точка зору, на наш погляд, $є$ помилковою з таких підстав. Поперше, вона грунтується на ототожненні статті Особливої частини КУпАП з нормою закону, що визначає склад проступку. Варто зауважити, що проблема співвідношення норми права й статті нормативного акта давно привертає увагу вчених-юристів. Тут найбільш плідними виявилися дослідження представників кримінального права. Складно не погодитися з їхніми висновками про те, що стаття закону може бути частиною норми, а норма може міститися в декількох статтях і навіть у низці законодавчих актів, оскільки норма - це правило, а стаття законодавчого акта - лише форма викладу думки законодавця і форма вираження його державної волі.

По-друге, аналіз Особливої частини КУпАП показує, що диспозищії будь-якої статті не містять повного переліку всіх ознак складу. Наприклад, у даних статтях немає вказівок на вік правопорушника, його осудність, намір тощо. Ці ознаки, будучи загальними для всіх адміністративних правопорушень, закріплюються нормами Загальної частини КУпАП.

Відповідно до другої точки зору, адміністративно-правова норма, що закріплює склад проступку, синтезується з положень Загальної та Особливої частин КУпАП. Загальна частина закріплює ознаки, що є обов'язковими для будь-якого 
проступку (вік, із досягненням якого настає адміністративна відповідальність, форми вини), і в статтях Особливої частини не фігурують. Остання закріплює конкретні (особливі) ознаки адміністративних правопорушень. Таке «розчленування» адміністративно-правової норми за статтями Загальної й Особливої частин КУпАП здійснено з єдиною метою: щоб десятки разів не повторювати загальні ознаки при визначенні конкретного адміністративного правопорушення.

Усі ознаки складу адміністративного правопорушення взаємопов'язані і взаємозалежні, тобто їхня сукупність становить цілісне системне утворення. Візьмемо для прикладу дрібне розкрадання (ст. 51 КУпАП). Самі собою такі його ознаки, як чуже майно, намір, досягнення 16-річного віку тощо, узяті як окремо, так і в сукупності, нічого вартого осуду не містять, але коли вони об' єднуються законодавцем у відповідній нормі, як ознаки конкретного протиправного діяння, перед нами виникає юридична модель адміністративного правопорушення (його склад).

3 визнання такої властивості складу, як цілісність, випливає важливий висновок: якщо в діянні немає хоча б однієї з ознак, що містяться в складі, то в ньому немає і цього складу, тобто воно не може бути кваліфіковане за конкретною статтею на основі норми права, що закріплює певний склад. Це означає, що в діянні або є інший склад, або немає жодного.

Велике практичне значення має виділення постійних і перемінних ознак складів адміністративних правопорушень. Постійними вважаються ті, що чітко визначені правовою нормою, теорією або усталеною практикою. Наприклад, чітко зафіксований зміст понять «піднаглядний», «транспортний засіб», «пішохід» тощо.

Перемінними називають ознаки, зміст яких чітко не зафіксований. Їхній перший різновид становлять ті ознаки, що містяться у відсилочних нормах [9, с. 197-199] і змінюються підзаконними актами. Наприклад, законом установлена відповідальність за порушення правил санітарії (статті 42, 43, 107 КУпАП), благоустрою населених пунктів (ст. 152 КУпАП), тримання собак і кішок (ст. 154 КУпАП). Ці правила можуть установлюватися, змінюватися, скасовуватися органами управління, що тягне зміну ознак відповідних складів.

Другий різновид перемінних ознак - оцінні. Зміст таких ознак у нормативному порядку чітко не визначається і питання про їхню наявність або відсутність вирішується практичними працівниками з урахуванням конкретних обставин. Наприклад, це «грубе порушення» (статті 85, 86, 108 КУпАП), «забезпечення необхідних умов життя, навчання та виховання» (ст. 184 КУпАП), «об'єкти, що сприяють масовому скупченню птахів, небезпечних для польотів повітряних суден» (ст. 111 КУпАП).

За ступенем узагальнення розрізняють ознаки: а) загальні; б) родові або видові; г) конкретні або одиничні. Загальні ознаки властиві всім складам (протиправність, осудність, вина тощо). Родові (видові) характерні для групи складів. Наприклад, для складів, що описують правопорушення в галузі стандартизації, якості продукції, метрології і сертифікації, специфічним буде об'єкт зазіхань - це суспільні відносини, що складаються в згаданій сфері. Конкретні (одиничні) характеризують окремі конкретні склади. Наприклад, ідеться про «нецензурну лайку» (ст. 173 КУпАП), «проституцію» (ст. 181-1 КУпАП), «організатора вуличного походу» (ст. 185- 1 КУпАП).

Важливу роль розуміння співвідношення ознак фактичних та ознак складу (апостеріорних й апріорних ознак) та, відповідно, онтології і гносеології проступку відіграє при розв'язанні питання про його шкідливість або суспільну небезпеку. Вказане питання є дискусійним ще з середини XX століття і донині, [10, с. 75]. На 
нашу думку, розгортання дискусії з приводу шкідливості або суспільної небезпеки як ознаки адміністративного проступку має два (поза всяким сумнівом, пов' язаних між собою) аспекти, - політичний і юридичний.

Політичний аспект полягає в тому, що визнання за адміністративним деліктом ознаки суспільної небезпеки вказує на його генетичні зв'язки зі злочином, дає підстави для виключного використання для його позначення терміна «адміністративний проступок», залишає можливість позначити неправомірні дії терміном «адміністративне правопорушення». Невизнання за адміністративним деліктом ознаки суспільної небезпеки дає можливість створення конщепщії щодо його особливої правової природи, яка пов' язана із соціалістичним суспільством, затушувати питання про правову природу адміністративного судочинства.

Юридичний аспект цієї дискусії витікає з близькості адміністративних проступків (деліктів) і кримінальних правопорушень (злочинів). У літературних джерелах відзначається, що зазначені види правопорушень, як соціальні явища, є дуже близькими між собою, а межі між ними - досить рухливі та умовні. 3 цього приводу зауважимо, що законодавча практика знає випадки, коли перші з них перетворюються на другі й навпаки. Тобто одне й те саме діяння на одному проміжку часу розцінюється як злочин, а на іншому - як адміністративний проступок [11, с. 9-10]. Прикладом може слугувати адміністративна відповідальність за дрібне хуліганство. У перші роки їі існування, незалежно від кількості виконаних особою протягом року складів, наступала саме вона. 3 перебігом часу законодавець прийшов до висновку про доцільність кримінальної відповідальності спочатку за третє, а потім за друге дрібне хуліганство. Згодом кримінальна відповідальність за дрібне хуліганство була скасована. Сьогодні законодавство України кримінальної відповідальності за дрібне хуліганство не знає. Аналіз кримінальних й адміністративних справ показує, що за значний проміжок часу властивості дрібного хуліганства майже не змінилися, а от їхня правова оцінка - істотно.

Отже, усе залежить від волевиявлення законодавця, вираженого в праві й зумовленого соціально-політичними та іншими потребами суспільства, а також ситуацією, що в ньому склалась.

Зазначене у відповідній мірі збігається з тезою про те, що між різними категоріями правопорушень об'єктивно існує лише кількісна відмінність у ступені суспільної небезпеки, а якісну відмінність надає законодавець.

Ця якісна відмінність значною мірою проявляла себе в зміні процедури притягнення правопорушника до відповідальності. Як відомо, суб'єктом застосування заходів відповідальності до злочинця є суд. Суб'єктом застосування заходів відповідальності до адміністративного правопорушника є, як правило, посадові особи органів управління. Зміна процедури притягнення до відповідальності порушувала просте питання: чому для покарання за скоєння певних правопорушень законодавець в одних випадках надає перевагу адміністративним, а в інших - судовим засобам? Відповідлю мав стати матеріальний (об'єктивний) критерій відокремлення адміністративних правопорушень від злочинів. У ході його пошуку формуються два підходи. Відповідно до першого, адміністративні делікти є діяннями, що мають суспільну небезпеку. Відповідно до другого, адміністративні делікти є діяннями шкідливими. 
Прихильники оцінки адміністративного правопорушення, як явища, що не є суспільно небезпечним, спираються на твердження про те, що злочини - це якісно особливий вид правопорушень, а їхня основна матеріальна властивість полягає в суспільній небезпечності. Остання повно характеризує виключно злочини, а для інших правопорушень ця ознака не є обов'язковою. При цьому вказують на норми КК України, які містять визначення злочину як суспільно небезпечного діяння, i фіксують, що не є злочином дія чи бездіяльність, яка хоч формально і містить ознаки будь-якого діяння, передбаченого КK, але через малозначність не становить суспільної небезпеки, тобто не заподіяла й не могла заподіяти істотної шкоди фізичній чи юридичній особі, суспільству або державі (ч. 2 ст. 11 КК України). Отже, у праві чітко закріплено, що малозначний протиправний вчинок не є суспільно небезпечним і не може розглядатись, як злочин. Відповідно до цього положення, виходять два висновки.

По-перше, ознака суспільної небезпеки властива тільки злочинам, інші правопорушення позбавлені цієї якості. По-друге, адміністративні правопорушення (проступки) не становлять собою суспільної небезпеки; це суспільно шкідливі, антигромадські явища.

Шкідливість розглядається як властивість, наявність якої виключає суспільну небезпеку і визнається критерієм, за яким адміністративні правопорушення відокремлюються від інших порушень правових норм, насамперед від злочинів. Злочини й відрізняються від адміністративних правопорушень тим, що перші є діяннями суспільно небезпечними, а другі - це діяння лише шкідпиві.

Науковці, які розглядають адміністративні правопорушення як суспільно небезпечні діяння, зазначають, що їх вихідною позицією є матеріальна єдність усіх правопорушень. Тому суспільна небезпека - це ознака, властива їм усім без винятку. Відмінність полягає лише в ступені суспільної небезпеки. Злочини мають підвищений ступінь суспільної небезпеки. Адміністративним правопорушенням вона властива меншою, невеликою, невисокою, незначною мірою, не досягаючи того рівня, $з$ якого починається застосування заходів кримінальної відповідальності.

Л. В. Коваль 3 цього приводу зазначає, що суспільна небезпека є однією з основних ознак адміністративного правопорушення та його об' єктивною властивістю; учений розглядає їі як критерій а) диференціації адміністративних проступків між собою, б) розмежування адміністративних проступків і злочинів. Далі робиться висновок про те, що більшість адміністративних проступків відрізняеться від злочинів меншим ступенем суспільної небезпеки, відсутністю великої шкоди для суспільства, яку завдають йому злочини [12, с. 15].

Вихідною позищією поглядів $Є$. В. Додіна на проблему співвідношення суспільної небезпеки і шкоди як характеристик адміністративного делікту є судження про наявність якісних відмінностей між злочином й адміністративним проступком. Такі відмінності, на думку $Є$. В. Додіна, знаходять зовнішній вираз у категорії «характер». 3 цього приводу вчений зазначає, що у філософії категорія «якість» трактується як «визначеність об' єкта». Вона становить собою цілісну і відносно стійку сукупність ознак, що визначають його специфіку й риси подібності з іншими об'єктами. Цю визначеність злочинам надає особливий характер суспільної небезпеки. Саме характер суспільної небезпеки, а не ступінь суспільної небезпеки відрізняе 
злочини від адміністративних деліктів. Ступінь - показник кількості. Нагромадження суспільної небезпеки в силу закону діалектики переходу кількості у якість перетворює проступок на якісно нове явище - злочин [13, с. 34-35].

У кримінальному праві вчення про суспільну небезпеку діяння розвинулось у межах соціологічної школи. У доктрині суспільна небезпека визнається матеріальною ознакою будь-якого злочину і характеризується кількісними та якісними властивостями. Їхня сукупність визначає тяжкість посягання загалом. Якісна властивість називається характером суспільної небезпеки, а кількісна - їі ступенем. Характер суспільної небезпеки визначається суспільною цінністю об'єкта злочину (родового й безпосереднього), на який посягає злочинець. Ступінь суспільної небезпеки зумовлюється розміром завданої шкоди, способом вчинення злочину, місцем, обстановкою та стадіями його вчинення, формою вини, мотивом і метою, а також особою винного. Ступінь суспільної небезпеки остаточно виражений у санкції кримінально-правової норми. Суспільна небезпека виявляється в певному рівні шкідливості для суспільства. Зменшення цього рівня інколи завершується втратою суспільної небезпеки діяння, тобто воно перестає бути злочином. Зокрема, суть кримінально-правової норми про малозначність полягає в тому, що лише формальної, зовнішньої схожості діяння зі злочином ще недостатньо для визнання його таким. Вирішення цього питання віднесено до компетенщії правозастосувача. Малозначне діяння, що не містить складу злочину через відсутність суспільної небезпеки, може утворювати склад іншого правопорушення (наприклад, адміністративного чи дисциплінарного проступку).

Значення суспільної небезпеки полягає в тому, що вона, по-перше, є основним критерієм визнання діяння злочинним, тобто підставою його криміналізації; подруге, дає змогу класифікувати злочини за ступенем тяжкості; по-третє, визначає межу між злочинами та іншими правопорушеннями (зокрема, адміністративними проступками); по-четверте, є однією із загальних засад індивідуалізації кримінальної відповідальності.

З огляду на зазначене, в українській адміністративно-правовій концепщії існує три варіанти вирішення проблеми співвідношення шкідливості й суспільної небезпеки як ознак адміністративного проступку.

Перший погляд (Л. В. Коваль) полягає в тому, що поняття «суспільна небезпека» є загальним. Характеристики загального - це а) ступінь і б) кількість. Ступінь визначається питомою вагою шкоди, а кількість - повторністю та рецидивом. Другий погляд (I. П. Голосніченко) зводиться до того, що загальним є поняття «шкідливість». Зростання або зниження питомої ваги шкідливості утворює відповідну ступень суспільної небезпеки. Третій погляд (С. В. Додін) полягає в тому, що поняття «суспільна небезпека» є загальним. Характеристики загального - це а) характер, що має якісний зміст; і б) ступінь, що має кількісний зміст. Зростання або зниження питомої ваги кількісних показників відповідно до законів діалектики впливає на якісний зміст, тобто на характер.

Отже, незважаючи на тривалість дискусії щодо проблеми суспільної небезпеки адміністративних правопорушень, можна констатувати спільність поглядів ії учасників у визнанні негативного характеру всіх правопорушень. Негативна ж оцінка не може полягати в чомусь іншому, крім шкоди й суспільної небезпеки. Водночас представники дискусійних точок зору не знайшли достатніх аргументів, які б дали 
змогу прийняти одну з позищій за основу і здійснювати подалыші дослідження проблем шкідливості й суспільної небезпечності адміністративних деліктів шляхом створення спільної базової концепщії.

Загальною вадою поглядів фахівців, котрі беруть участь у відповідній полеміці, на нашу думку, є пріоритет логіко-понятійного підходу до обгрунтування своїх аргументів і доказів. Залежно від того, який зміст вкладається в поняття «шкода» і «суспільна небезпека», робиться висновок: а) про їхню наявність або відсутність серед ознак адміністративного проступку; б) загальний характер одного з понять відносно другого; в) пріоритетність одного перед іншим у формуванні категорії «адміністративний проступок (делікт)». Ми вважаємо за можливе запропонувати новий підхід щодо об'єктивного розмежування категорій «шкода» і «суспільна небезпека». Цей підхід грунтується на сучасних висновках філософії права й полягає в дослідженні зазначених категорій із позицій а) правової онтології; б) правової гносеології.

Застосування онтологічних і гносеологічних знань як методів дослідження адміністративно-деліктного середовища свідчить, що поняття «шкода», «шкідливість», «суспільна шкода», «об'єктивна шкідливість діяння» $є$ онтологічними категоріями і проявляються в емпіричному вимірі. Наявність шкоди, як правило, встановлюється шляхом опису, який сам собою вже виступає доказом шкідливості відповідного діяння. Недаремно законодавець застосовує зазначене поняття як первісну ознаку правопорушення. Так адміністративний проступок визнається вчиненим, коли особа, яка його вчинила, передбачала, бажала, свідомо допускала можливість настання шкідливих наслідків своєї дії чи бездіяльності (ст. 10 і ст. 11 КУпАП). Відповідно до закону, потерпілим є особа, якій адміністративним правопорушенням заподіяно моральну, фізичну або майнову шкоду (ст. 269 КУпАП). Вимога зазначати в документі, який описує факт вчинення адміністративного проступку (протоколі про адміністративний проступок), наявність матеріальної шкоди (ст. 256 КУпАП) також свідчить про онтологічну природу категорії «шкода».

Суспільна небезпека - це гносеологічна категорія. Ії неможливо встановити шляхом онтологічного опису того, що трапилось. Вона доводиться шляхом дослідження всіх ознак і характеристик факту дійсності, у нашому випадку - правопорушення. Дослідження всього комплексу властивостей правопорушення здійснюється у відповідних організаційних формах - справах про адміністративні проступки, кримінальних справах, дисциплінарних справах тощо. Такі справи по своїй суті є гносеологічним відбитком конкретного діяння. Розслідування справи є пізнанням (дослідженням) факту реальної дійсності, в онтології якого виявились ознаки правопорушення (кримінального, адміністративного, дисциплінарного тощо).

За КК України особу, яка вперше вчинила злочин невеликої або середньої тяжкості, крім корупційних злочинів, може бути звільнено від кримінальної відповідальності, якщо буде визнано, що на час кримінального провадження, внаслідок зміни обстановки, вчинене нею діяння втратило суспільну небезпечність або ця особа перестала бути суспільно небезпечною. Зауважимо, що в законі йдеться саме про суспільну небезпеку, а не про шкоду або шкідливість. Тим самим законодавець підкреслює, що діяння втрачає не онтологічну ознаку «шкідливість», а гносеологічну - суспільну небезпеку.

У цьому контексті важливим аргументом на користь гносеологічності категорії «суспільна небезпека» $є$ нормативне закріплення юридичного значення суб'єктивного компоненту (позищії дослідника) в остаточному вирішенні питання про 
суспільну небезпеку діяння. За Кримінальним процесуальним кодексом України слідчий, прокурор, слідчий суддя, суд за своїм внутрішнім переконанням, яке грунтується на всебічному, повному й неупередженому дослідженні всіх обставин кримінального провадження, керуючись законом, оцінюють кожний доказ із точки зору належності, допустимості, достовірності, а сукупність зібраних доказів - із точки зору достатності та взаємозв' язку для прийняття відповідного процесуального рішення. Жоден доказ не має наперед встановленої сили. Це означає, що кожний із суб'єктів доказування в межах своєї компетенції здійснює відшукання (виявлення), процесуальне закріплення, дослідження та оцінку доказів. Оцінщі підлягає кожен доказ окремо і всі в сукупності. При оцінщі окремих доказів враховується специфіка їхніх джерел, а також вироблені наукою, перевірені практикою та історичним досвідом особливості оцінки цих джерел (наприклад, при оцінщі показань свідків враховуються особливості психологічного процесу їхнього формування).

Методами такої оцінки є, зокрема, аналіз самого факту, а також порівняння (зіставлення) певного факту з іншими доказами, що містяться в справі. Ії результатом $\epsilon$ внутрішнє переконання про відсутність чи наявність суперечності міждоказом, що виявлений знову, і доказами, зібраними раніше. Встановлені суперечності слугують підставою для пошуків засобів їх вирішення шляхом відшукання та оцінки нових фактів. Кінщевим результатом цієї діяльності є формулювання висновків у справі. При цьому кожен суб'єкт доказування (суддя, прокурор, слідчий) робить такі висновки самостійно і незалежно від інших учасників процесу.

Побічною вказівкою на онтологічний характер фактичних ознак адміністративного проступку, які зафіксовані в протоколі про адміністративний проступок (ст. 256 КУпАП), і гносеологічний характер ознак, що містяться в постанові по справі про адміністративний проступок (ст. 283 КУпАП), слід визнати термінологію, яку застосовує законодавець у відповідних випадках.

Так протокол про адміністративний проступок складається, а постанова по справі про адміністративний проступок виноситься. Термін «складання» означає поєднання в сукупність незмінюваних предметів, частин, ознак. Термін «винесення» походить від слова «виноска», що означає пояснення чого-небудь. Останнє містить оцінку суб'єктом пояснення існуючих у дійсності фактів, обставин, предметів, а тому є гносеологічною категорією.

Відповідно до міркувань щодо співвідношення понять «шкідливість» і «суспільна небезпека», необхідно відзначити, що термін «суспільна небезпека» КУпАП не використовує. Утім аналіз чинного законодавства України дозволяє стверджувати, що законодавець пов 'язує суспільну небезпеку з будь-яким правопорушенням.

Висновки. Отже, є достатньо підстав вважати «шкідливість» онтологічною ознакою об'єктивної сторони правопорушення (не складу, а суто діяння), притаманною злочинам та адміністративним проступкам. Гносеологічною ознакою об'єктивної сторони складу правопорушення, яка притаманна злочинам й адміністративним проступкам, є «суспільна небезпека». Ії наявність або відсутність у шкідливому діянні доводиться під час розслідування відповідних справ, яке полягає в досліджені та оцінщі уповноваженим суб'єктом усіх обставин, що стосуються цього діяння, і формулюванні висновку щодо його (діяння) кваліфікації. У такому висновку (постанова у справі про адміністративний проступок, вирок суду) фактично фігурує гносеологічна ознака об'єктивної сторони складу правопорушення 
- «суспільна небезпека». Таким чином, адміністративним правопорушення (проступком) є діяння, у гносеології якого встановлено ознаки його складу.

\section{Використані джерела:}

1. Завгородня Л. О. Особливості кваліфікації правопорушень, передбачених статтею 172-7 Кодексу України про адміністративні правопорушення. Правова держава. 2018. № 31. С. 31-37.

2. Братковський В. М. Ознаки адміністративного порушення законодавства про мобілізаційну підготовку та мобілізацію. Науковий вісник Міжнародного гуманітарного універсuтетy. 2017. № 26. C. 48-52.

3. Самбор М. А. Правопорушення та проступок: до питання співвідношення понять в умовах розвитку законодавства про адміністративні та кримінальні правопорушення. Юридична наука. 2013. № 8. С. 39-48.

4. Колпаков В. К. Парадигма «поняття адміністративного права»: зміст і новели в системі універсалій. Питання адміністративного права. Кн. 3 / відп. за вип. Н. Б. Писаренко. Харків: Право, 2019. С. 48-75.

5. Адміністративне право України. Повний курс: підручник / Галунько В. та ін. Херсон: ОЛДІ-ПЛЮС, 2019.520 с.

6. Музиченко Г. В. Адміністративне право та процес. Конспект лекщій. Одеса: Південноукраїнський національний педагогічний університет імені К. Д. Ушинського, 2020. $366 \mathrm{c.}$

7. Кравцова Т. М. Адміністративне право: навчальний посібник. Суми: СВС Панасенко, 2015. 308 c.

8. Алфьоров С. М., Ващенко С. В., Долгополова М. М., Купін А. П. Адміністративне право. Загальна частина: навч. посіб. Київ: Центр учбової літератури, 2011. 216 с.

9. Колпаков В. К. Бланкетні та відсилочні склади адміністративного проступку. Юридичний науковий електронний журнал. 2016. № 2. С. 197-199.

10. Колпаков В. К., Гордєєв В. В. Теорія адміністративного проступку: монографія. Харків: Харків юридичний, 2016. 344 с.

11. Коломоєць Т. О., Колпаков В. К. Вступ до навчального курсу «Адміністративне право України»: навч. лекція Київ: Ін Юре, 2014. 240 с.

12. Коваль Л. В. Відповідальність за адміністративні правопорушення: монографія. Київ: Вища школа, 1975. 104 с.

13. Додин Е. В. Правонарушения в системе механизма торможения социальноэкономического развития страны. Роль органов внутренних дел в преодолении антиобщественных проявлений: сборник научных трудов. Киев: НИиРИО КВШ, 1988. С. 32- 37.

\section{References:}

1. Zavhorodnia, L. O. (2018) Osoblyvosti kvalifikatsii pravoporushen, peredbachenykh statteiu 172-7 Kodeksu Ukrainy pro administratyvni pravoporushennia. Pravova derzhavaConstitutional state, 31, 31-37. [in Ukrainian].

2. Bratkovskyi, V. M. (2017) Oznaky administratyvnoho porushennia zakonodavstva pro mobilizatsiinu pidhotovku ta mobilizatsiiu. Naukooyi visnyk Mizhnarodnoho humanitarnoho universytetu- Scientific Bulletin of the International Humanities University, 26, 48-52. [in Ukrainian].

3. Sambor, M. A. (2013) Pravoporushennia ta prostupok: do pytannia spivvidnoshennia poniat $\mathrm{v}$ umovakh rozvytku zakonodavstva pro administratyvni ta kryminalni pravoporushennia. Yurydychna nauka-Legal Science, 8, 39-48. [in Ukrainian]. 
4. Kolpakov, V. K. (2019) Paradyhma «poniattia administratyvnoho prava»: zmist i novely v systemi universalii. Pytannia administratyvnoho prava. Part. 3. Pysarenko N. B. (Ed.). Kharkiv: Pravo, 48-75. [in Ukrainian].

5. Administratyvne pravo Ukrainy. Povnyi kurs: pidruchnyk (2019) Halunko V. (Ed.) et al. Kherson: OLDI-PLIuS. [in Ukrainian].

6. Muzychenko, H. V. (2020) Administratyvne pravo ta protses. Konspekt lektsii. Odesa: Pivdennoukrainskyi natsionalnyi pedahohichnyi universytet imeni K. D. Ushynskoho. [in Ukrainian].

7. Kravtsova, T. M. (2015) Administratyvne pravo: navchalnyi posibnyk. Sumy: SVS Panasenko.[in Ukrainian].

8. Alforov, S. M., Vashchenko, S. V., Dolhopolova, M. M., Kupin, A. P. (2011) Administratyvne pravo. Zahalna chastyna: navch. posib. Kyiv: Tsentr uchbovoi literatury. [in Ukrainian].

9. Kolpakov, V. K. (2016) Blanketni ta vidsylochni sklady administratyvnoho prostupku. Yurydychnyi naukooyi elektronnyi zhurnal-Legal scientific electronic journal, 2, 197-199. [in Ukrainian].

10. Kolpakov, V. K., Hordieiev, V. V. (2016) Teoriia administratyvnoho prostupku: monohrafiia. Kharkiv: Kharkiv yurydychnyi. [in Ukrainian].

11. Kolomoiets, T. O., Kolpakov, V. K. (2014) Vstup do navchalnoho kursu «Administratyvne pravo Ukrainy»: navch. Lektsiia. Kyiv: In Yure. [in Ukrainian].

12. Koval, L. V. (1975) Vidpovidalnist za administratyvni pravoporushennia: monohrafiia. Kyiv: Vyshcha shkola. [in Ukrainian].

13. Dodin, E. V. (1988) Pravonarusheniya v sisteme mekhanizma tormozheniya social'noekonomicheskogo razvitiya strany. Rol' organov vnutrennih del v preodolenii antiobshchestvennyh proyavlenij: sbornik nauchnyh trudov. Kyiv: NIiRIO KVSH, 32-37. [in Ukrainian].

Стаття надіӥшиа до редколегї̈ 12.01.2020

Коломоец Т. А., доктор юридических наук, профессор, член-корреспондент НАПрН Украины, заслуженный юрист Украины, декан юридического факультета Запорожского национального университета (г. Запорожье, Украина) Колпаков В. К., доктор юридических наук, профессор, заведующий кафедрой административного и хозяйственного права Запорожского национального университета (г. Запорожье, Украина)

\section{УНИВЕРСАЛИИ «ФАКТИЧЕСКИЙ ПРИЗНАК» И «ПРИЗНАК ЮРИДИЧЕСКОГО СОСТАВА» В ПОНЯТИИ АДМИНИСТРАТИВНОГО ПРАВОНАРУШЕНИЯ}

В статье исследуется соотношение универсалий «фактический признак» и «признак юридического состава» административного правонарушения. На основании их онтологогносеологического анализа раскрыто содержание и практическое значение апостериорньх и априорных признаков административного проступка. Акцентировано внимание на роли 
указанных признаков в разработке понятий «общественная вредность административного правонарушения» И «общественная опасность административного правонарушения». Предложено новое видение генезиса, правовой природы, соотношения ипонимания указанных универсалий. На основании проведенного исследования сформулировано доктринальное определение административного правонарушения.

Ключевые слова: административное правонарушение; онтология и гносеология административного правонарушения; фактические признаки и юридический состав административного правонарушения; общественная опасность и общественная вредность административного проступка.

Kolomoyets T.,

Doctor of Law, Professor, Corresponding Member of the National Academy of Sciences of Ukraine, Honored Lawyer of Ukraine, Dean of the Law Faculty at Zaporizhzhya National University (Zaporizhzhya, Ukraine) Kolpakov V.,

Doctor of Law, Professor, Head of the Department of Administrative and Business Law at Zaporizhzhya National University (Zaporizhzhya, Ukraine)

\section{THE UNIVERSALS "ACTUAL SIGN" AND "SIGN OF LEGAL COMPOSITION" IN THE CONCEPT OF ADMINISTRATIVE MISCONDUCT}

The article examines the actual signs of an administrative misconduct. Study the legal structure of an administrative misconduct. Study the laws on administrative misconducts. It explains the concept of the actual signs of an administrative misconduct. It explains the concept of the legal structure of an administrative misconduct. We investigate their relationship. Identify common characteristics and features of the administrative misconduct of an administrative misconduct.

The actual symptoms of this empirical signs. The actual signs sous-exist in the material world. The actual signs are established through observation. The article deals with the legal nature of the administrative tort law of Ukraine. To that end, studied the signs of the administrative tort. The author distinguishes between a posteriori and a priori signs of administrative tort. Posteriori signs are fixed by law. These features - the truth of facts. They are the same for any behavioral act. A priori characterize the individual behavioral act. They are the result of the analysis of a particular behavioral act. These features - the truth of logic. They allow to characterize behavioral act as an administrative tort.

The article deals with their classification according to the degree of public danger; the nature of the damage caused; guilty subjects; structural features; regulation in the legislation. The author proves that a set of a priori evidence of individual behavioral act is a system. Signs of legal structure of an administrative misconduct gnoseological signs. Signs of legal structure of an administrative misconduct need to be proved. In it a difference between the actual signs of an administrative misconduct and signs of structure of an administrative misconduct. Problem in the following: a) the administrative misconduct when is the actual signs; $b$ ) the administrative misconduct when is signs of structure of an administrative misconduct. Signs which are directly listed by the law in particular article 9 code of Ukraine about administrative misconducts, are signs a posteriori. Signs which the concept "structure of administrative misconduct" contains are signs aprioristic.

The ratio a posteriori and aprioristic is that knowledge which was gained previously by practical consideration (a posteriori knowledge, knowledge the acquired from experience, empirical 
knowledge, truth of the fact) precede further experience, will organize and direct it. Act as the tool which serves for receiving and formation of new knowledge of theoretical level (aprioristic knowledge, knowledge the acquired from consciousness, theoretical knowledge, truth of reason).

From here follows: to truly consider "harm" as an ontologic sign of the objective party of an misconduct which is inherent in crimes and administrative misconducts. Gnoseological a sign of the objective party of structure of an misconduct which is inherent in crimes and administrative misconducts is "public danger".

Its existence or absence in harmful action is proved during the investigation of the corresponding affairs. Proof consists: a) in research and an assessment by the subject of investigation of all circumstances of act; b) to the formulation of the conclusion about its qualification. The sign of the objective party of structure of an misconduct - "public danger" actually appears in it the conclusions (the resolution on the case of administrative misconduct, a sentence of court) gnoseological.

On the basis of differentiation of the actual signs of an administrative misconduct from signs of structure of an administrative misconduct the ratio is investigated: a) public harm of an administrative misconduct; b) public danger of an administrative misconduct. It is proved:1) Public harm - ontology of an administrative misconduct. Public harm - a posteriori sign of an administrative misconduct; 2) Public danger - gnoseology of an administrative misconduct. Public danger - an aprioristic sign of an administrative misconduct.

Main conclusion: an administrative misconduct is act in gnoseology of which existence of signs of structure of an administrative misconduct is proved.

Keywords: administrative misconduct; misconduct ontology; misconduct gnoseology; actual indication of an misconduct; legal components of an misconduct; posteriori legal signs of an misconduct; aprioristic legal signs of an misconduct; public danger of an administrative misconduct; public harm of an administrative misconduct.

DOI: 10.33766/2524-0323.89.162-172

УДК 342.95:349.6(477)

В. М. Комарницький, доктор юридичних наук, професор,

провідний науковий співробітник науково-дослідної лабораторії з проблем попередження, припинення та розслідування злочинів територіальними органами

Національної поліції України Луганського державного університету внутрішніх справ імені Е. О. Дідоренка

(м. Сєвєродонецьк, Україна) e-mail:mail@lduvs.edu.ua

iD https:/ / orcid.org/0000-0003-1510-2395

\section{АДМІНІСТРАТИВНА ВІДПОВЦДАЛЬНІСТЬ ЗА ПРАВОПОРУШЕННЯ У СФЕРІ ОЩНКИ ВПЛИВУ НА ДОВКІЛЛЯ}

У статті досліджено питання, пов'язані з регулюванням адміністративної відповідальності у сфері оцінки впливу на довкілля. Зокрема, акцентовано увагу на проблемі визначення складів адміністративних правопорушень, що посягають на встановлений порядок здійснення оцінки впливу на довкілля, а також обгрунтовано

(c) Комарницький В. М., 2020 